two main purposes : the provision of part of the approved capital cost of acquisition and installation of grain-drying equipment and storage facilities ; and assistance in the provision of plant, equipment and working capital for agricultural co-operative societies and other approved associations of farmers.

\section{AMERICAN PHILOSOPHICAL SOCIETY} YEAR BOOK FOR 1952

$\mathrm{T}$ HE year book for 1952 of the American Philosophical Society* includes a brief history of the Society and a copy of the charter, together with the list of members and the customary obituary notices and list of publications during the year; besides this it gives, in the report of the committee on research, lists of grants made during the year January 1December 31, 1952, from the three research funds administered by the Society as follows: from the Penrose Fund, which is unrestricted, 133 grants totalling 123,250 dollars; from the Johnson Fund, nine grants totalling 20,687 dollars; and from the Daland Fund, which is limited to research in clinical medicine, three grants totalling $\mathbf{3 , 7 5 0}$ dollars. Brief reports from recipients of grants, arranged alphabetically by sciences, are also included. Among the longer of these summaries may be mentioned those of the following: M. D. Taylor on the vapour-phase dissociation of formic, propionic and acetic acids, indicating that formic acid possesses by far the weakest hydrogen bond, acetic and propionic acids possessing bonds of nearly equal strength; R. W. Chaney, comparing the Cenozoic floras of Japan with those of corresponding age in North America, and indicating that Metasequoia was widely distributed and abundant at high northern latitudes during Cretaceous and Tertiary time; H. P. Hansen on his investigation of post-glacial forest migrations and climate in western Canada and Alaska by means of pollen analysis of peat sections ; R. J. Drake on a study of the species (and distribution) of the nonmarine molluse fauna of Sonora (Mexico); W. B. Jackson on microclimatic factors in army ant behaviour and ecology; and A. Loveridge on ecological studies on the vanishing fauna of rainforest remnants in tropical East Africa. F. A. McDermott reports further data on Jamaican Lampyridæ, M. C. Carlsen on plant collecting in southern Mexico and Honduras, $\mathbf{H}$. A. Imshaug on a taxonomic and phytogeographic study of the lichen flora of the Rocky Mountains, Hui-Lin Li on a study of the Scrophulariace of China, H. E. Moore, jun., on native and cultivated palms of the western hemisphere, and H. T. Skinner on character patterns in the Amorican azaleas.

K. J. Hayes records an analysis of chimpanzee intelligence, and in biochemistry J. L. and E. M. Irvin report on their spectrophotometric study of the interaction of quinoline and acridine derivatives with plasma proteins, nucleic acids and nucleoproteins. W. J. Eversole summarizes studies which indicate a physiological role of secretions of the adrenal medullary hormones in water and electrolyte metabolism; G. R. Seaman, metabolic studies on the growth factor protogen; L. S. Crossman, studies

* American Philosophical Society. Year Book, 1952. January 1. 1952-December 31, 1952. Pp. 486+1 plate. (From the Socjety, Philadelphia, Penn., 1953. on the prehistory of the Oregon coast; and M. I. Hilger, an ethnological field study of the beliefs, customs and traditions in the development, rearing and training of the Araucanian Indian child of Chile. Besides E. M. Kampa's investigation of the photosensitive pigments in marine animals in the vicinity of Bermuda, which indicates the observation of at least one new photosensitive pigment, there are briefer reports on eight other investigations by scientists working at the Bermuda Biological Station for Research, including aspects of phosphate metabolism, the luminous bacteria-bacteriophage system, the metabolic effects of sinus gland removal in land Crustacea, the sponges of Bermuda, cell-growth and development as affected by changes in oxidationreduction potential, and parasitological studies of fishes.

\section{STANDARD FREQUENCY TRANSMISSIONS FROM THE UNITED KINGDOM}

CTANDARDS of frequency and time differ from $S$ other standards of measurement in that they can be made available continuously over wide areas by means of radio transmissions. The frequencies of $2 \cdot 5,5,10,15,20$ and $25 \mathrm{Mc}$./s. have, by international agreement, been allocated for this purpose; and for several years past, a continuous service on all these frequencies (and also on 30 and $35 \mathrm{Mc}$./s.) has been operating from station $W W V$ of the National Bureau of Standards, near Washington, D.C.

Such transmissions enable the user to standardize his equipment without costly and elaborate apparatus, but to be fully effective they must be received in all parts of the world. The $W W V$ transmissions do not meet this requirement, and experiments on an international scale are therefore being conducted under the general direction of the International Radio Consultative Committee in order to discover the best means of securing world-wide coverage.

As the United Kingdom's contribution to this work, a limited programme of transmissions has been made daily since February 1950 from the Post Office station at Rugby under the call-sign $M S F$. On May 26 this year the programme was extended to provide a continuous (twenty-four hours a day) service of transmissions on the three frequencies of $2 \cdot 5,5$ and $10 \mathrm{Mc} . / \mathrm{s}$. Later, 15 and $20 \mathrm{Mc} / \mathrm{s}$. may be used, but only three frequencies will be transmitted simultaneously. The signals are identified by a speech announcement made at fifteen-minute intervals, while during five-minute periods the carrier waves are modulated in turn by a 1,000-c./s. tone and by $1-\mathrm{c} . / \mathrm{s}$. pulses, the fifty-ninth pulse in each minute being omitted. A supplementary local service for use within the United Kingdom is also provided by a special transmission at a frequency of $60 \mathrm{kc} . / \mathrm{s}$. for a period of one hour daily.

Full details of these new transmissions are given in a pamphlet issued by the National Physical Laboratory, Teddington, under the title " $M S F-$ New Programme of Experimental Frequency Transmissions from the United Kingdom". The carrier and modulation frequencies are all obtained from the same standard and are maintained within \pm 2 parts in $10^{\circ}$ of their nominal values. The transmissions are regularly monitored at the National Physical Laboratory, and the results of daily measurements on 
$60 \mathrm{kc} . / \mathrm{s}$. are published monthly in the Wireless Engineer. Although the absolute frequency cannot be determined with certainty to better than one part in $10^{8}$, relative values are known to one part in $10^{8}$; and as the day-to-day stability is of interest to some users, the results are published to this accuracy.

These transmissions from the United Kingdom are interrupted during the interval 15-20 minutes past each hour so that one station alone can be measured under conditions where, for example, the signals from two stations such as $M S F$ and $W W V$ are being received at nearly equal strengths. This break in transmission will also permit measurements of radio noise to be made if no other transmission is present.

\section{JOHN HENRY NEWMAN AND SCIENCE}

$\mathrm{D}^{\mathrm{n}}$ URING 1852 J. H. Newman delivered a series of lectures in University College, Dublin, which were known as "Discourses on the Scope and Nature of University Education". They are now usually read, as finally published in 1873, under the title of "The Idea of a University Defined and Illustrated". Newman founded the University College and was its first principal for some years. Opinions differ concerning the value of his work in Ireland-even Shane Leslie thought that it was a failure-but a series of lectures, given a century after Newman's endeavours to put before the Irish his ideas concerning the aims and functions of a university, were delivered by leading members of the staff of the institution which he founded and helped to create.

Prof. T. S. Wheeler* has dealt systematically and with commendable objectivity with Newman's views on the place of science in a university. Although Newman regarded the teaching of science and professional subjects as a duty of a university, nevertheless he considered the development of the mind the primary end of university education. His object was to form, particularly in his junior students, a cultivated intellect on which other knowledge could be grafted. Although Newman insisted that he had been fighting liberalism all his life, he intended his objections to concern the liberalism which was more recently known as rationalism or scientific humanism. He was a champion of a liberal education in the modern sense. A 'gentleman' was one who had been improved and sensitized by such an education (but even in his day Newman was not the only antagonist of the more partial of Locke's educational theories). Newman insisted that it is only the mind trained and developed by a liberal culture that can profitably absorb and utilize knowledge of all kinds. On one hand, we have to distrust the view that the liberally educated man can control everything-"a view that has flowered to its greatest exuberance in the Civil Service" (and is occasionally found in modern universities). On the other hand, we have to face the dangers which arise from over-specialization. Since Newman wrote, science has developed at an enormous rate. About a million scientific papers are published each year, and the scientist is overwhelmed by a flood of knowledge. As a result, there is more and more pressure of material for inclusion in a university course and an increasing tendency to specialization. The point of view of the average

- "Newman and Science." By Prof. T. S. Wheeler. Studies. An Irlsh Quarterly Review. (The Talbot Press, Dablin, Summer 1953.) science graduate is narrow : neither at school nor at the university does he receive the training which Newman regarded as fundamental, except in rare cases. There is an increasing complaint that scientists know more and more about less and less, and that they are not always able to express themselves clearly by mouth and pen. If this is true, the disease is more apparent than the remedy; but it is satisfactory to note that in England most schools are trying to do something to overcome the intellectual narrowness of both their science and their arts students; and, if little has yet been done, the universities are at least aware of the needs.

Prof. Wheeler comments as follows : "In Newman's view the great object of a university is to make something or other of its students and not simply to protect the interests and advance the dominion of science. The modern estimate of the place of research in a university department of science is completely at variance with that of Newman ; though he tended to modify these views later in life. At present, discovery is regarded as more important than teaching, and the standing of a science department is determined by the quality of the research work it produces rather than by the quality of its teaching. The plums in the academic profession go to the research worker. The good teacher seldom reaches the top". (In the modern university there is, of course, the 'good organizer' whose abilities and qualifications it is extremely difficult to define.)

Surprisingly, Newman was alive to the need for the development of teaching applied science in his University. The Great Exhibition of 1851 had shown that British industry was losing its premier place owing to the manner in which Continental nations were fostering applied science. The teaching of engineering, agriculture and medicine involves a practical as well as an academic approach and yet these subjects have been successfully incorporated in a university discipline.

Since the 'thirties of this century we have had theories, in spate, of the aims and nature of a university : we have had Allison Peers in "Red Brick", Moberly in "Post-War Crisis", the Harvard Report, Goodhart and Livingstone from an old university, Colonial and international conferences, the 'synthetics' of the Anglo-American peripatetics, and so on. In the midst of all this there is still something of relevance in the elegant writings of Newman. W. L. SUMNER

\section{STRUCTURAL BASIS OF THE CROSS-STRIATIONS IN MUSCLE By Dr. JEAN HANSON* and
Dr. HUGH E. HUXLEY ${ }^{\circ}$}

Department of Biology, Massachusetts Institute of Technology, Cambridge, Massachusetts

$T$ HE myofibrils of striated muscle consist largely of protein (more than 90 per cent of their dry weight $)^{1}$, and it is believed ${ }^{2}$ that the only proteins present in significant quantities are myosin, actin and probably a small amount of tropomyosin. We shall describe here evidence that the cross-striation of the

- Fellow of the Rockefeller Foundation. On leave from the Medical Research Council Biophysics Research Ünit, King's College, Strand, Research Council

+ Fellow of the Commonwealth Fund. On leave from the Medical Research Council Unit for the Study of the Molecular Structure of Biological Systems, Cavendish Laboratory, Cambridge. 